\title{
KETERAMPILAN MEMBACA DAN MENULIS DALAM MENINGKATKAN BERPIKIR KRITIS DAN LITERASI SAINS ${ }^{1}$
}

\author{
Oleh: Nur Wakhidah ${ }^{2}$
}

\begin{abstract}
Abstrak
Keterampilan membaca diperlukan dalam bidang apapun termasuk dalam matapelajaran IPA. Dengan membaca orang akan memahami sesuatu dan memperoleh informasi. Seseorang dikatakan telah paham apabila dapat menerima informasi dan dapat menginformasikan kembali. Penyampaian informasi kembali dapat melalui bahasa lisan maupun tulisan. Menulis juga merupakan keterampilan yang diperlukan untuk menyampaikan gagasan dalam rangka berpikir kritis dan kreatif. Dalam membaca dan menulis terdapat keterampilan berpikir tingkat tinggi yaitu berpikir kritis. Dengan berpikir kritis saat memahami bacaan maka seseorang juga akan mempunyai kecenderungan untuk kritis dalam menyampaikan ide-ide melalui bahasa tulis. Keterampilan dalam membaca literatur dan menuliskan konsep yang telah dibaca dan ditulisnya diharapkan dapat meningkatkan literasi sains.
\end{abstract}

Kata kunci: berpikir kritis, keterampilan menulis, keterampilan membaca, literasi sains

\section{A. Keterampilan Abad 21}

Perkembangan ilmu pengetahuan dan teknologi membawa manusia kedalam kesejahteraan dan kemudahan dalam kehidupan. Dampak negatif yang muncul ketika terjadinya perkembangan iptek adalah adanya persaingan persaingan global. Bagi mereka yang mempunyai kemampuan untuk bersaing akan survive, sedangkan yang tidak mampu bersaing akan tersingkirkan. Dalam skala global baik individu maupun negara harus mampu untuk menghadapi tantangan dunia global, dimana negara-negara di dunia saling bersaing untuk maju dan menjadi negara yang sejahtera. Untuk menghadapi

\footnotetext{
${ }^{1}$ Disampaikan pada seminar nasional Prodi Pendidikan Sains S1 Unesa tahun 2012

2 Dosen PGMI Fak. Tarbiyah IAIN Sunan Ampel Surabaya dan mahasiswa S3 Pendidikan Sains Unesa
} 
abad 21 yang penuh dengan persaingan global maka kita harus membekali diri dengan keterampilan yang dibutuhkan untuk memasuki abad 21 yang telah berjalan satu dekade.

Keterampilan abad 21 yang perlu dikuasai oleh seseorang antara lain keterampilan berpikir kritis, keterampilan memecahkan masalah, keterampilan berpikir kreatif, ketrampilan mengambil keputusan, keterampilan untuk membaca dan menulis reflektif, keterampilan berkomunikasi baik secara lisan maupun tertulis. Apabila kurikulum 2013 benar-benar akan diterapkan maka keterampilan membaca dan menulis akan menjadi suatu keniscayaan bagi guru Sd/MI karena matapelajaran IPA akan dimasukkan ke dalam pelajaran bahasa Indonesia dan matapelajaran lain yang sifatnya tematik. Pembekalan keterampilan ini kepada calon guru sangat diperlukan bila kurikulum tersebut benar akan diterapkan pada tahun depan.

\section{B. Keterampilan Membaca dan Menulis dan Keterampilan Berpikir Kritis}

Di negara Eropa dan Jepang aktivitas menulis dan membaca dilakukan selama 5 jam sampai dengan 7 jam perhari, sedangkan di Indonesia pelajar belum meluangkan waktu khusus (0 jam) untuk aktivitas membaca dan menulis (Kedaulan Rakyat, 2008:7) yang dikutip oleh Pujiono (2011). Akibatnya pelajar di Indonesia tidak mempunyai kemampuan membaca dan menulis yang baik. Apalagi proses pembelajaran menulis di sekolah/lembaga pendidikan kurang menarik dan cenderung membosankan.

Berpikir kritis berarti berpikir melalui suatu proses sadar. Bila tidak akan berisiko dikendalikan oleh ide-ide orang lain. Inti dari berpikir kritis adalah kita dapat memikirkan dan mengambil sikap terhadap gambar visual pada televisi layar, janji-janji memikat iklan, mengelak atau mengomentari pernyataan oleh beberapa orang dalam berita dan propaganda, dan menilai penalaran/pemikiran yang rusak. Untuk terlibat dalam berpikir kritis kita akan menjadi sepenuhnya menyadari ide atau tindakan, merefleksikan hal itu, dan akhirnya bereaksi terhadap hal itu. Sebenarnya, kita sudah terlibat dalam Proses ini berkali-kali setiap hari. Misalnya, berpikir kritis ketika kita bertemu 
orang baru dan memutuskan apakah Anda menyukai orang tersebut; ketika kita membaca buku dan membentuk pendapat itu didasarkan pada analisis yang masuk akal; atau ketika kita wawancara untuk pekerjaan dan kemudian mengevaluasi persyaratan dan kemampuan kita untuk memenuhinya (Anonim, 2012).

Langkah-langkah dalam proses berpikir kritis sepertinya mirip dengan langkah dalam menulis. Langkah tersebut adalah:

1. Meringkas. Melakukan ekstraksi dan menyatakan kembali pesan utama materi

2. Analisis. Memeriksa materi dengan memecahnya menjadi beberapa bagian. Dengan melihat setiap bagian dari keseluruhan sebagai unit yang berbeda, kita menemukan bagian-bagian saling berhubungan.

3. Mensintesis. Menarik benang merah apa yang telah dirangkum dan dianalisa dengan menghubungkannya ke pengalaman sendiri, seperti membaca, berbicara dengan lain, menonton televisi dan film, dengan menggunakan internet, dan sebagainya. Cara ini membuat kita tahu secara keseluruhan dan memperoleh pengetahuan dan wawasan yang dikombinasikan dengan pengetahuan sebelumnya

4. Evaluasi. Menilai kualitas dari tulisan yang kita buat apakah sudah sesuai dengan yang telah kita baca dan pengetahuan kita sebelumnya.

Jika kita mencermati dari langkah menulis di atas maka kita dapat melihat bahwa menulis juga merupakan proses kritis dimana kita dalam menulis kita juga melibatkan proses berpikir tingkat tinggi yaitu analisis, sintesis dan evaluasi (Fascione, 2011). Bagaimana hubungan berpikir kritis dengan proses membaca? Membaca adalah proses yang aktif, dinamis berarti membuat interaksi antara yang dibaca dengan memori di otak. Memahami proses membaca membantu orang menjadi pemikir yang kritis. Membuat prediksi adalah aktivitas utama dalam proses membaca. Pikiran kita terus menebak apa yang akan terjadi selanjutnya. Ketika kita melihat informasi berikutnya, kita akan dapat menegaskan atau merevisi prediksi kita. Misalnya, Saat kita membaca majalah dengan judul "The Heartbeat."Pikiran kita mulai 
menebak: Apakah ini sebuah kisah cinta? Apakah ini tentang bagaimana jantung memompa darah? Mungkin, kita berkata kepada diri sendiri, itu adalah cerita tentang seseorang yang mengalami serangan jantung. Kemudian, saat kita membaca beberapa kalimat pertama, pikiran kita memprediksi hal yang benar. Jika kita melihat kata-kata seperti impuls listrik, serat otot, dan kontraksi, maka kita langsung tahu bahwa kita berada di ranah fisiologi. Dalam kalimat lagi, kita dapat mempersempit prediksi ke salah satu "Jantung sebagai pompa" atau "jantung menderita serangan. "Untuk membuat prediksi secara efisien, kita harus membacanya sampai tuntas.

Membaca majalah akan berbeda dengan cara membaca buku teks kuliah. Membaca majalah dapat dilakukan dengan sekilas tanpa harus mengulang. Akan tetapi kita juga dapat mengulangnya untuk mendapatkan informasi yang lebih jelas. Membaca bahan kuliah hendaknya dilakukan berulang sehingga lebih dapat memahaminya. Seberapa detail kita membaca tergantung dari materi dan tujuan kita membaca. Jika telah mengenal topiknya maka kita tidak perlu terlalu lama maengulang. Konsep yang telah umum dapat dibaca secara sekilas. Untuk materi baru dan materi yang kompleks dan abstrak diperlukan intensitas membaca yang lebih banyak. Tipe membaca terkait dengan tujuan dibedakan menjadi:

1. Membaca untuk arti harfiah, untuk melihat apa yang dinyatakan.

2. Membaca untuk menarik kesimpulan, untuk melihat apa yang tidak dinyatakan tetapi tersirat.

3. Membaca untuk mengevaluasi, untuk membentuk pendapat sendiri tentang materi.

Membaca untuk makna literal berarti membaca untuk pemahaman. Tujuannya untuk menemukan gagasan utama, rincian pendukung, atau, dalam sebuah karya fiksi, pusat rincian plot dan karakter. Membaca makna literal tidak semudah kedengarannya. bila kita menemukan sebuah konsep baru, dan memikirkannya. Ketika kita membaca untuk mengevaluasi misalnya menilai karya penulis evaluatif dapat dilakukan setelah kita merangkum, menganalisis, 
dan mensintesis materi. Membaca kritis adalah berpikir tentang apa yang kita baca. Cara-cara untuk meningkatkan pemahaman bacaan adalah:

1. Membuat asosiasi. Menghubungkan materi baru dengan apa yang sudah diketahui, terutama ketika sedang membaca tentang konsep sulit. Kita dapat membaca hal yang lebih mudah untuk membantu menghubungkan konsep lama dan baru

2. Buatlah serelaks mungkin dengan mendengarkan musik.

3. Butuh waktu yang cukup

4. Menguasai kosa kata tersebut.

Dengan membaca, kita mencoba berdialog dengan mempertanyakan isi bacaan, merespon, menunjukan keraguan atau menunjukan rasa setuju atas pernyataan-pernyataan yang kita baca, kita tengah belajar menjadi pembaca yang kritis. Menceritakan isi dari apa yang sedang kita baca kepada teman pun merupakan hal yang ampuh untuk menguji pemahaman kita terhadap isi bacaan serta mengasah kemampuan berpikir kritis. Jika kita sudah terbiasa menjadi pembaca aktif dan berdialog dengan apa yang kita baca, kita akan mengasah kemampuan berpikir kritis dan pada akhirnya akan meningkatkan kemampuan menulis kritis. Semakin kita banyak membaca dan berdialog dengan bacaan, maka kita dapat meningkatkan kemampuan menulis (Kompas, 2012).

Meringkas berbeda dengan mensintesis. Sintesis terjadi setelah kita membuat ringkasan yang dikembangkan melalui proses berpikir kritis. Untuk mensintesis perlu menyusun materi bersama-sama bahan dari beberapa sumber, termasuk pengetahuan pribadi sebelumnya sehingga menghasilkan pengetahuan baru. Untuk mensintesis perlu menerapkan strategi. Misalnya, membandingkan

ide dalam sumber-sumber, ide kontras dalam sumber, membuat definisi yang menggabungkan dan memperluas definisi dalam sumber-sumber individual, menerapkan contoh atau deskripsi dari satu sumber untuk menggambarkan ide- 
ide di tempat lain, dan menemukan penyebab dan efek yang dijelaskan dalam satu sumber yang menjelaskan yang lain.

\section{Keterampilan Berpikir Kritis dan Literasi Sains}

Menurut Programme for International Student Assessment (PISA, 2006), Literasi sains adalah kemampuan menggunakan pengetahuan sains untuk mengidentifikasi permasalahan dan menarik kesimpulan berdasarkan bukti-bukti dalam rangka memahami serta membuat keputusan tentang alam dan perubahan yang dilakukan terhadap alam melalui aktivitas manusia. Literasi sains menurut National Science Education Standards (1998) adalah: Scientific literacy is knowledge and understanding of scientific concepts and processesrequired for personal decision making, particsainstion in civic and cultural affairs, and economicproductivity. It also includes specific types of abilities.

Menurut Organization for Economic Cooperation and Development (OECD, 2003) literasi sains (scientific literacy) didefinisikan sebagai kapasitas untuk menggunakan pengetahuan ilmiah,mengidentifikasi pertanyaan dan menarik kesimpulan berdasarkan fakta untuk memahami alamsemesta dan membuat keputusan dari perubahan yang terjadi karena aktivitas manusia. Literasisains penting untuk dikuasai oleh siswa dalam kaitannya dengan bagaimana siswa dapat memahamilingkungan hidup, kesehatan, ekonomi dan masalah-masalah lain yang dihadapi oleh masyarakat modern yang sangat bergantung pada teknologi dan kemajuan serta perkembangan ilmu pengetahuan (Yusuf, 2003).

Literasi sains didefinisikan oleh AAAS (American Association for the Advancement of Science) dengan "Project 2061" sebagai kapasitas untuk menggunakan pengetahuan ilmiah, mengidentifikasi pertanyaanpertanyaan dan untuk menarik kesimpulan berdasarkan bukti-bukti agar dapat memahami dan membantu membuat keputusan tentang dunia alami dan interaksi manusia dengan alam. Literasi sains dianggap suatu hasil 
belajar kunci dalam pendidikan pada usia 15 tahun bagi semua siswa, apakah meneruskan mempelajari sains atau tidak setelah itu. Berpikir ilmiah merupakan tuntutan warganegara, bukan hanya ilmuwan karena siswa dapat berpikir secara ilmiah tentang bukti yang akan mereka hadapi.

Literasi sains suatu pengetahuan dan pemahaman mengenai konsep dan proses sains yang akan memungkinkan seseorang untuk membuat suatu keputusan dengan pengetahuan yang dimilikinya, serta turut terlibat dalam hal kenegaraan, budaya dan pertumbuhan ekonomi, termasuk di dalamnya kemampuan spesifik yang dimilikinya. Literasi sains dapat diartikan sebagai pemahaman atas sains dan aplikasinya bagi kebutuhan masyarakat. Jadi Literasi sains merupakan kemampuan menggunakan pengetahuan sains, mengidentifikasi permasalahan dan menarik kesimpulan berdasarkan bukti-bukti, dalam rangka mengerti serta membuat keputusan tentang alam dan perubahan yang terjadi pada alam sebagai akibat manusia dalam kehidupan sehari-hari.

Yildirim (2012) Berpikir kritis adalah gabungan dari sikap, pengetahuan dan keterampilan yang meliputi: Sikap penyelidikan yang melibatkan kemampuan untuk mengetahui adanya masalah dan penerimaan bukti umum untuk melakukan abstraksi, dan generalisasi secara logis. Berpikir kritis sudah dirintis oleh John Dewey pada tahun 1930 tentang berpikir reflektif yaitu memikirkan sesuatu dengan sungguhsungguh dengan pertimbangan rasional. Enis (1985) berpendapat bahwa berpikir kritis rasional adalah berpikir reflektif peduli dengan apa yang harus dilakukan atau percaya apa yang dia lakukan.

Paul (1992) mengatakan bahwa berpikir kritis adalah seni berpikir tentang berpikir, yaitu berpikir jernih, tepat, akurat, relevan, konsisten, dan terbuka. Ini adalah seni kritik konstruktif, seni mengidentifikasi dan menghapus bias, prasangka, dan keberpihakan pada satu pemikiran. Pada tahun 2006 definisi Facione tentang pendekatan untuk berpikir kritis meliputi analisis, interpretasi, kesimpulan, penjelasan, evaluasi, dan selfregulasi. Berpikir kritis merupakan proses yang mendukung keyakinan dan 
tindakan. Fisher (2001) menyimpulkan bahwa berpikir kritis tergantung pada kepercayaan nilai dan sikap. Berpikir kritis merupakan pusat pemikiran reflektif, dan itu adalah proses yang berprinsip dan menggunakan keterampilan kognitif interpretasi, analisis, kesimpulan, penjelasan evaluasi, dan self-regulasi berpikir rekursif (Facione et al 2000).

Yildirim (2011) mendefinisikan berpikir kritis adalah "proses mencari, memperoleh, mengevaluasi, menganalisis, mensintesis dankonseptualisasi informasi sebagai panduan untuk mengembangkan pemikiran seseorang dengan kesadaran diri, dan kemampuan untuk menggunakan informasi dengan menambahkan kreativitas dan berani mengambil risiko ".

Kemampuan bagi siswa untuk menggunakan pemikiran independen dan menggabungkan konsep belajar untuk memecahkan masalah situasi yang realistis (Bruning, 2005). berpikir kritis adalah metode untuk mengevaluasi argumen atau proposisi dan membuat penilaian yang dapat memandu perkembangan kepercayaan dan mengambil tindakan (Astleitner, 2002). Komponen berpikir kritis menurut Fascione adalah sebagai berikut:

\section{Core Gritical Thinking Skills Analysis \\ Inference}

Explanation

Interpretation Thinking

Self-Regulation Evaluation 
Interpretasi terjadi ketika individu memahami dari berbagai pengalamnanya termasuk mengkategorikan, decoding, menjelaskan, mengenali masalah tanpa prasangka, dan membedakan gagasan utama dari ide-ide tambahan. Analisis adalah ketika pelajar mengidentifikasi hubungan yang dituju dan inferensial antara pernyataan, dan termasuk pemeriksaan ide, analisis argumen dan mengidentifikasi asumsi tak tertulis. Evaluasi meliputi kemampuan pelajar untuk mempertimbangkan kredibilitas asumsi dan membandingkan kekuatan dan kelemahan dari pandangan-pandangan alternatif berdasarkan keyakinannya. Inferensi mengacu pada kemampuan seseorang untuk membangun makna dan untuk mengidentifikasi implikasi dari posisi tertentu.

CONSENSUS LIST OF CT COGNITIVE SKILLS AND SUB-SKILLS (Fascione, 1990)

\begin{tabular}{|l|l|l|}
\hline No & SKILL & SUB-SKILLS \\
\hline 1 & Interpretation & $\begin{array}{l}\text { Categorization } \\
\text { Decoding Significance } \\
\text { Clarifying Meaning }\end{array}$ \\
\hline 2 & Analysis & $\begin{array}{l}\text { Examining Ideas Identifying Arguments } \\
\text { Analyzing Arguments }\end{array}$ \\
\hline 3 & Evaluation & $\begin{array}{l}\text { Assessing Claims } \\
\text { Assessing Arguments }\end{array}$ \\
\hline & Inference & $\begin{array}{l}\text { Querying Evidence } \\
\text { Conjecturing Alternatives } \\
\text { Drawing Conclusions }\end{array}$ \\
\hline & Explanation & $\begin{array}{l}\text { Stating Results } \\
\text { Justifying Procedures } \\
\text { Presenting Arguments }\end{array}$ \\
\hline
\end{tabular}

Belajar sains sebagai cara berpikir meliputi keyakinan (belief), rasa ingin tahu (curiosity), imaginasi (imagination), penalaran (reasoning), hubungan sebab-akibat (cause-effect relationship), 
pengujian diri dan skeptis (self-examination and skeptiscism), keobjektifan dan berhati terbuka (objectivity and open-mindedness). Sebagai cara untuk menyelidiki belajar sains dapat berupa metode ilmiah, yang titik beratnya adalah berhipotesis (hypothesis), pengamatan (observation), melakukan eksperimen (experimentation), dan menggunakan matematika (mathematics). Sains sebagai pengetahuan (body of knowledge) meliputi fakta (facts), konsep-konsep (concepts), hukum-hukum dan prinsip-prinsip (laws and principles), teori-teori (theories) dan model-model (models). Sains dalam interaksinya dengan teknologi dan masyarakat telah banyak dipelajari dalam berbagai bentuk pembelajaran seperti STS, SETS, serta pembelajaran sains kontektual seperti CTL (Liliasari, 2011).

Philips (2003) yang dikutip oleh Coll \& Taylor ( 2011) berpendapat bahwa literasi ilmiah istilah telah digunakan untuk mencakup berbagai komponen dari berikut ini:

1. Pengetahuan tentang isi substantif dari ilmu pengetahuan dan kemampuan untuk membedakan dari non-ilmu pengetahuan;

2. Memahami ilmu pengetahuan dan penerapannya;

3. Pengetahuan tentang apa yang dianggap sebagai ilmu;

4. Kemerdekaan dalam pembelajaran ilmu pengetahuan;

5. Kemampuan untuk berpikir secara ilmiah;

6. Kemampuan menggunakan pengetahuan ilmiah dalam pemecahan masalah

7. Pengetahuan yang dibutuhkan untuk partisipasi cerdas dalam ilmu pengetahuan berbasis masalah;

8. Memahami sifat ilmu pengetahuan, termasuk hubungannya dengan budaya;

9. Apresiasi dan kenyamanan dengan ilmu pengetahuan, termasuk heran dan rasa ingin tahu;

10.Pengetahuan tentang risiko dan manfaat dari ilmu pengetahuan, dan 
11.Kemampuan untuk berpikir kritis tentang ilmu pengetahuan dan berurusan dengan keahlian ilmiah.

Keterampilan berpikir kritis dan pengambilan keputusan sangat diperlukan manusia dalam memecahkan masalah sehari-hari. Apakah dalam kondisi hujan saya harus berangkat ke kampus maka saya harus berpikir kritis apa yang harus saya lakukan terlebih dahulu saya harus memikirkan apa yang akan terjadi jika saya nekat berangkat saat hujan sangat deras sementara saya tidak mahir dalam menyetir mobil. Harus diperhitungkan apakah jalannya licin atau tidak, apakah jalannya macet atau tidak, berapa menit saya sampe kesana, sepatu dilepas atau tidak, nanti terlambat atau tidak kalau terlambat ditinggal mahasiswa atau tidak, kalau kehujanan nanti sakit atau tidak, perlu dipikirkan dan sekaligus segera diambil suatu tindakan. Untuk itu diperlukan keterampilan berpikir tingkat tinggi

Untuk dapat berpikir secara analisis dan evaluatif seperti di atas diperlukan pengetahuan akan kesehatan, pengetahuan untuk memprediksi kondisi jalan dan lain-lain. Sebagai contoh dalam kegiatan pembelajaran, supaya mahasiswa dapat memecahkan permasalahan yang terkait dengan pencemaran lingkungan maka mereka harus tahu apakah arti pencemaran, sejauh mana suatu perairan dikatakan tercemar, apa parameter dan indikatornya, zat pencemarnya apa. Untuk melakukan problem solving diperlukan literasi sehingga pendekatan problem solving tampaknya efektif jika masalah yang diberikan kepada mahasiswa cenderung kontekstual dan sangat berhubungan dengan apa yang ada di sekitarnya. Bila pencemaran dihubungan dengan skala global yang mahasiswa tidak mengetahui informasi tersebut maka dapat dipastikan mahasiswa kurang efektif dalam melakukan problem solving. Mengaingat hal tersebut maka dalam proses pembelajaran seyogyanya guru menyediakan lingkungan belajar yang kondusif bagi terselenggarakan 
model pembelajaran berbasis masalah untuk meningkatkan literasi dan pemahaman konsep baik visual, audio dan verbal.

\section{Literasi Sains dan Pendidikan Karakter}

Orang yang mengerti atau memahami sesuatu hal maka orang tersebut mempunyai kecenderungan untuk melakaukan sesuatu yang dapat merugikan diri sendiri maupun orang lain. Orang yang sadar akan bahaya merokok maka akan berusaha berhenti untuk merokok bahkan kadangkadang saat mereka dinyatakan dalam paru-parunya terdapat infeksi. Mereka yang mengetahui bahwa tumbuhan di malam hari juga melakukan proses pernapasan maka tidak akan menaruh pot yang ditanami tumbuhan hidup di dalam kamarnya, meskipun pada siang hari akan menambah kesejukan. Anak yang mengetahui dan paham akan sains tidak bermain layang-layang saat hujan rintik dan berpotensi terjadinya petir. Anak atau mahasiswa yang telah melakukan praktikum melakukan praktikum pengaruh zat pencemar terhadap kehidupan organisme air tidak membuang air buangan limbah detergen dengan kadar tinggi ke dalam tanah atau air karena dia mengetahui akan menimbulkan pencemaran. Dengan mengatahui, memahami, melakukan, memikirkan, menulis dan mengkomunikasikan secara lisan maupun tertulis maka diharapkan siswa mampu mempunyai sikap misalnya tidak membuang sampah sembarangan, peduli akan kesehatannya dan lingkungan sosial. Orang merokok dapat membahayakan dirinya. Dia paham dan tidak melakukan. Selain itu juga dia tahu kalau melakukan akan merugikan orang lain. Sikap ini akan muncul ketika dia tahu dan paham akan bahayanya terhadap diri dan lingkungannya. Literasi sains akan membantu manusia dalam pembentukan sikap positif bila benar-benar diajarkan dengan tepat. Hal ini sesuai dengan hakikat pembelajaran sains yaitu sains sebagai produk, sains sebagai proses dan sains sebagai nilai atau sikap. 


\section{DAFTAR PUSTAKA}

Yusuf. S. (2003). Literasi Siswa Indonesia Laporan PISA 2003. Jakarta: Pusat Penilaian Pendidikan.[Online]. Tersedia: http://www.p4tksains.org. [18 Juni 2008].

OECD. (2003). Chapter 3 of the Publication "PISA 2003 Assesment of framework - mathematics, Reading, Science and problem solving knowledge and skills. [Online]. Tersedia: http://www.oecd.org /dataoecd /38/29/33707226.pdf. [18 Juni 2008].

Liliasari. 2011. Membangun Masyarakat Melek Sains Berkarakter Bangsa Melalui Pembelajaran. Bandung: Prodi Pendidikan IPA SPS

Coll Richard K. \& Neil Taylor. 2009. The Meaning of Scientific Literacy. International Journal of Environmental \& Science Education Vol. 4, No. 3, 275-288

Jordan, Sheila. 2012. Character Based Literacy. USA: Santa Clara University Winton Ave Harvard.

Pujiono, S. 2011. Berpikir Kritis Dalam Literasi Membaca Dan Menulis Untuk Memperkuat Jati Diri Bangsa. Yogyakarta: JPBSI.

http://edukasi.kompasiana.com/2012/02/06/berpikir-kritis-membaca-kritismenulis-kritis/ Diakses tanggal 12-12-12

Anonim.2012. Ketrampilan Membaca dan Menulis Adalah Proses berpikir Kritis. http://www.interlink.edu/claroline/uncg diakses tanggal 12-12-12.

Yildirim, Belgin. Dan Sukran Ozkahraman. 2012. Critical Thinking in Nursing and Learning Styles. International Journal of Humanities and Social Science Vol. 1 No. 18

OECD. (2003). Chapter 3 of the Publication "PISA 2003 Assesment of framework - mathematics, Reading, Science and problem solving knowledge and skills. Tersedia: http://www.oecd.org/dataoecd /38/29/33707226.pdf. [18 Juni 2008]. 
PISA. (2006). Science Competencies for Tomorrow's World Volume 1analysis.OECD. [Online]: www.oecd.org/statistics/statlink. [ 8 Juli 2008]

AAAS. 2006. Benchmarks for Science Literacy A tool for Curriculum reform. http://www.Project2061.org/publication/bs1/online. diakses 1 Oktober 2011

Yildirim, Belgin. Dan Sukran Ozkahraman. 2012. Critical Thinking in Nursing and Learning Styles. International Journal of Humanities and Social Science Vol. 1 No. 18

Dewey, J (1933). How we think. Boston: DC. Heath and Co, 16

Enis, R. (1985). A logical basis for measuring critical thinking skills. Educational Leadership, 43, 45-48.

Facione, N.C. (1995). Critical thinking and clinical judgment: Goals 2000 for nursing science. Paper presented at the Annual Meeting of the Western Institute of Nursing, San Diego, CA.

Facione, P.A. (2006), Critical thinking: what it is and why it counts. [Online] Available: www.calpress.com/pdf_files/what\&why.pdf (May 17, 2011).

Paul, R. (1992). Critical thinking: what every person needs to survive in a rapidly changing world (2nd). Rohnert Park, CA: Center for Critical Thinking and Moral crique, Sonoma State University.

Astleitner, H. (2002). Teaching critical thinking online. Journal of Instructional Psychology, 29, 53-76. 